\title{
Nutritive cost of intraguild predation on eggs of Coccinella septempunctata and Adalia bipunctata (Coleoptera: Coccinellidae)
}

\author{
Jean-Louis HEMPtinNE ${ }^{1 *}$, Anthony Frederic George DiXON² and Catherine GAUTHIER ${ }^{3}$ \\ ${ }^{1}$ Ecole nationale de Formation agronomique, BP 87, F-31326 Castanet-Tolosan, France \\ ${ }^{2}$ School of Biological Sciences, University of East Anglia, NR4 7TJ Norwich, UK \\ ${ }^{3}$ Rue Pascal, 11 F-59800 Lille, France
}

Key words. Adalia bipunctata, Coccinella septempunctata, Coccinellidae, ladybird beetles, intraguild predation on eggs, costs, larval development, survival, alkaloids

\begin{abstract}
Coccinella septempunctata was approximately $20 \%$ more reluctant to eat the eggs of Adalia bipunctata than the reverse. In addition, fourth instar larvae of C. septempunctata failed to complete their development on a diet of $A$. bipunctata eggs and only $30 \%$ of those of $A$. bipunctata completed their development on a diet of $C$. septempunctata eggs, and the survivors took nearly 2 times as long as those fed aphids. This is an indication that the costs of intraguild predation might outweigh the benefits.
\end{abstract}

\section{INTRODUCTION}

Associated with large aggregations of prey are usually large numbers of insect predators belonging to several taxa (Rosenheim et al., 1993). For example, two or more species of anthocorid bugs, hoverflies, ladybirds, mirid bugs and parasitoids may all attack a population of sycamore aphids, Drepanosiphum platanoidis (Schrank), at the same time (Dixon \& Russel, 1972; Dixon, 1998). In summer, when immature individuals of the sycamore aphid become scarce the nymphs of Anthocoris confusus Reuter and A. nemorum (L.) resort to feeding on sycamore aphid mummies containing parasitoids. The proportion of anthocorid nymphs that reach maturity each year is dependent on the abundance of parasitized aphids (Dixon $\&$ Russel, 1972): when the main food resource becomes scarce the various members of this aphidophagous guild may resort to eating one another (Lucas et al., 1998; Obrycki et al., 1998a,b). Similarly, the frequency of intraguild predation in the field between the ladybirds Adalia bipunctata (L.), Coleomegilla maculata (De Geer) and Hippodamia convergens (Guerin) increases when the aphid population on maize crashes (Schellhorn \& Andow, 2000). In addition, many ladybirds like A. bipunctata choose to oviposit near large aggregations of aphids and as a consequence their eggs suffer a higher mortality from predation by other insect predators attracted by the aphids than species like C. maculata, which oviposits far from large aggregations of aphids (Schellhorn \& Andow, 1999). Intraguild predation is seen as adaptive as it supplies a source of food as well as removing potential competitors (Polis et al., 1989). As it is often asymmetrical (but see Rosenheim et al., 1995), with the sedentary stages of the various natural enemies more at risk of being eaten than the active stages, one would expect the more vulnerable species and stages to evolve means of avoiding being eaten. For example, parasitoids tend to cease ovipositing and leave areas where ladybirds are present and represent a threat to the survival of their offspring (Taylor et al., 1998). However, with a few notable exceptions little attention has been given to how species might defend themselves against intraguild predators (Canard \& Duelli, 1984; Eisner et al., 1996).

All stages of ladybirds contain species specific alkaloids, some of which are thought to be toxic to other ladybirds (Pasteels et al., 1973; Agarwala \& Dixon, 1992). However, the consequences of this toxicity for intraguild predation has been largely ignored.

All stages of $A$. bipunctata and Coccinella septempunctata $\mathbf{L}$. have been recorded coexisting in aphid colonies feeding, for example, on apple (Smee, 1922; Radwan \& Lövei, 1982; Hemptinne, 1989), peach (Remaudière \& Leclant, 1971), beans (Banks, 1955, 1956), broom (Smith, 1966), hops (Trouvé et al., 1996), maize (Radwan \& Lövei, 1983b), nettles (Hemptinne \& Naisse, 1988), spindle (Barczak et al., 1996) and wheat (Hemptinne, 1989). A. bipunctata is regarded as a polyphagous species (Nedvěd, 1999). Two surveys of the habitat preferences of predaceous ladybirds in Central Europe indicate that although both $A$. bipunctata and $C$. septempunctata have particular habitat preferences, shrubs and trees, and field plants, respectively, nevertheless, their habitat preferences do overlap and the indices of similarity cited range from 0.2-0.5 (Honěk, 1985; Nedvěd, 1999). Therefore, although intraguild predation between $A$. bipunctata and $C$. septempunctata has not been studied in the field it is likely to occur.

In this paper the effect of feeding fourth instar larvae of $A$. bipunctata and $C$. septempunctata on their own and the other species eggs was studied under laboratory conditions. In order to (a) exclude physical defence as a factor eggs rather than larvae were used as prey so that differences in performance of the predator could be attributed to nutritive effects, and (b) facilitate the measurement of performance fourth instar larvae were used as predators as they have the greatest growth potential of all the instars.

\section{MATERIALS AND METHODS}

\section{Ladybird culture}

The ladybirds were reared as previously described in Hemptinne et al., (1998) except the adults of $A$. bipunctata and C. septempunctata were kept at $15^{\circ}$ and $25^{\circ} \mathrm{C}$, respectively, in order to encourage egg production. The egg clusters were removed from the paper on which they were usually laid by cutting round them with fine scissors. From the beginning of the

\footnotetext{
* Corresponding author; jean-louis.hemptinne(a)educagri.fr
} 
third instar the larvae were isolated in 5-cm diameter Petri dishes lined with filter paper.

\section{Nutritive value of hetero- and conspecific eggs for fourth instar larvae of $\mathrm{A}$. bipunctata and $\mathrm{C}$. septempunctata}

A third instar larva of $A$. bipunctata was isolated in a $5-\mathrm{cm}$ diameter Petri dish and fed daily an excess of pea aphids (Acyrthosiphon pisum Harris). As soon as it moulted to the fourth instar, it was weighed. It was then fed daily an excess of pea aphids until it pupated when it was weighed again. This was repeated 19 times (control). The experimental procedure involved either feeding daily 15 larvae kept in isolation with batches of freshly laid conspecific eggs or 10 larvae with batches of eggs of $C$. septempunctata. Their survival, time spent in the fourth instar and consumption of eggs were recorded and their relative growth rates calculated as follows:

$$
\frac{\ln W_{f}-\ln W_{i}}{D}
$$

where $W_{f}$ is the weight of a pupa less than $24 \mathrm{~h}$ old, $W_{i}$ the weight of the larva at the beginning of the fourth instar and D the duration of the instar in days.

The mortalities were compared by means of $\chi^{2}$ tests, the duration of development and relative growth rates by means of Mann-Whitney's and Kruskal-Wallis tests and non parametric multiple comparisons (Zar, 1996).

The same experiment was repeated using fourth instar larvae of $C$. septempunctata. In this case 17 larvae were fed aphids, 17 conspecific eggs and 20 the eggs of $A$. bipunctata.

All these experiments were done at a temperature of $20^{\circ} \mathrm{C} \pm$ $1^{\circ} \mathrm{C}$, under artificial lighting of $2,000 \mathrm{lux}$. and a photoperiod of $16 \mathrm{~h}$ light and $8 \mathrm{~h}$ darkness.

\section{RESULTS}

\section{Nutritive value of hetero- or conspecific eggs for fourth instar larvae of :}

\section{(a) A. bipunctata}

Fourth instar larvae of $A$. bipunctata developed and survived as well on a diet of conspecific eggs as on a diet of pea aphids (Table 1). In contrast, a diet of C. septempunctata eggs resulted in $70 \%$ of the larvae dying, a mortality rate significantly greater than when fed either conspecific eggs or aphids $\left(\chi^{2}=16.57 ; 2 \mathrm{~d}\right.$. f.; $\mathrm{P}<0.001)$. Those that survived took significantly longer to complete the fourth instar (Kruskal-Wallis statistics $=22.861 ; 2$ d.f.; $\mathbf{P}<0.001$ ), and had a tendency to grow more slowly than larvae fed aphids or conspecific eggs (Kruskal-Wallis statistics $=6.536 ; 2$ d.f.; $\mathrm{P}=0.038)$. One of the three larvae that survived was lighter at the end than at the beginning of the fourth instar. Frequently, after ingesting yolk from seven-spot eggs, two-spot larvae were observed to vomit a black liquid.

\section{(b) C. septempunctata}

Larvae of $C$. septempunctata fed conspecific eggs grew significantly slower than those fed aphids (Mann- Whitney's U $=2.000 ; \mathrm{P}<0.001)$. Similarly, there was also a significant difference in the length of the fourth instar (Mann-Whitney's U $=282.000 ; \mathbf{P}<0.001 ;$ Table 1). However, as the larvae often ate all the eggs provided they were probably never satiated. It was not possible to give them more than 62 eggs per day on average because the supply of eggs was limited by the size of the culture of $C$. septempunctata. The observed differences in growth rate and development time could therefore result from a relative shortage of food.

A diet of eggs of $A$. bipunctata resulted in the death of all the larvae of $C$. septempunctata, after an average of 8.5 days. The mortality was significantly greater than that observed when larvae were fed pea aphids or conspecific eggs $\left(\chi^{2}=74.01 ; 2\right.$ d.f.; $\mathrm{P}<0.001$; Table 1). That is, the eggs of $A$. bipunctata appeared to be more toxic to $C$. septempunctata, than the reverse.

\section{DISCUSSION}

The study of Agarwala \& Dixon (1992) on A. bipunctata and C. septempunctata, that of Agarwala et al. (1998) on Menochilus sexmaculatus (F.) and C. transversalis and that of Cottrell \& Yeargan (1998) on Harmonia axyridis Pallas and C. maculata indicate that these species are more reluctant to eat each other's eggs than their own eggs. In the two first cases, interestingly, it is the eggs of the smaller species that are less likely to be eaten. This is also supported by our results. As all stages of ladybirds contain species specific alkaloids (Pasteels et al., 1973), which are known to be toxic to vertebrates (Frazer \& Rothschild, 1960; Marples et al., 1989), it is not unreasonable to assume that these alkaloids also afford the ladybirds protection from invertebrate predators. $A$. bipunctata adults contain more alkaloid per unit weight than C. septempunctata (de Jong et al., 1991; Holloway et al., 1991).

The results presented here on the incidence of predation by $A$. bipunctata on $C$. septempunctata eggs $(50 \%)$ and that of $C$. septempunctata on $A$. bipunctata eggs ( $30 \%$ ) are very similar to the $62 \%$ and $23 \%$, respectively, reported by Agarwala \& Dixon (1992). Therefore, A. bipunctata eggs appear to be more strongly protected than those of $C$. septempunctata. In addition, our results show that only $30 \%$ of the A. bipunctata larvae

TABLE 1. Number dying, egg consumption, duration of development and relative growth rate of fourth instar larvae of Adalia bipunctata and Coccinella septempunctata fed either pea aphids, conspecific or heterospecific eggs.

\begin{tabular}{|c|c|c|c|c|c|c|}
\hline & \multirow[t]{2}{*}{$\begin{array}{c}\mathrm{Nr} \text { of larvae } \\
\text { tested }\end{array}$} & \multirow[t]{2}{*}{$\begin{array}{l}\mathrm{Nr} \text { of larvae } \\
\text { dying }\end{array}$} & \multicolumn{2}{|c|}{$\begin{array}{l}\text { Average nr. of } \\
\text { eggs per larva }\end{array}$} & \multirow[t]{2}{*}{$\begin{array}{l}\text { Duration of 4th instar } \\
\text { (1) }\end{array}$} & \multirow[t]{2}{*}{$\begin{array}{c}\text { Relative growth rate } \\
\text { (1) }\end{array}$} \\
\hline & & & given & eaten & & \\
\hline \multicolumn{7}{|l|}{ A. bipunctata } \\
\hline Aphids & 19 & 2 & - & - & $4.1 \mathrm{a}$ & $0.143 \mathrm{a}$ \\
\hline Conspecific eggs & 15 & 1 & 205.2 & 159.7 & $6.1 \mathrm{~b}$ & $0.107 a, b$ \\
\hline Eggs of C. septempunctata & 10 & 7 & 159.3 & 74.3 & $7.0 \mathrm{~b}$ & $0.068 \mathrm{~b}$ \\
\hline \multicolumn{7}{|l|}{ C. septempunctata } \\
\hline Aphids & 17 & 0 & - & - & $4.1 \mathrm{a}$ & $0.266 \mathrm{a}$ \\
\hline Conspecific eggs & 17 & 0 & 388.5 & 281.7 & $6.5 \mathrm{~b}$ & $0.133 \mathrm{~b}$ \\
\hline Eggs of A. bipunctata & 20 & 20 & $\approx 350.0$ & 119 & & \\
\hline
\end{tabular}

(1) Figures followed by the same letter in the same column and for each species do not differ significantly at $\alpha=0.05$. 
completed their development on a diet of $C$. septempunctata eggs and took nearly two times longer to do so, whereas none of the $C$. septempunctata larvae completed their development on a diet of $A$. bipunctata eggs. This indicates that the eggs of both species are clearly toxic to the other species. As all stages of ladybirds contain similar concentrations of the species specific alkaloids (Pasteels et al., 1973), it could be assumed that all stages of both species are toxic to the other species. Although the prey in this study were eggs it is likely that similar results would have been obtained with larvae as prey.

In the field it is very unlikely that ladybird larvae would feed solely on ladybird eggs. It is more likely they eat ladybird eggs and larvae along with aphids, i.e., a mixed diet. However, when an aphid population on which ladybirds are feeding crashes the proportion of conspecific and heterospecific larvae in the diet may be very high. The eating of eggs and larvae of other species of ladybird is likely to reduce the quality of the diet of the ladybird. Poor quality food generally prolongs larval development in ladybirds (Blackman, 1965, 1967; Radwan \& Lövei, 1983a; Obrycki et al., 1998a,b), which as well as delaying maturity is also likely to increase the risk of the larvae being killed. Consequently, there are potential costs associated with intraguild predation.

In conclusion, well fed larvae should avoid eating the immature stages of other ladybirds because the costs in terms of prolonged development and decreased survival are potentially large. However, when starving the eating of the immature stages of other ladybirds, even though they are toxic, could be advantageous because it may prolong their survival, especially if combined with other more acceptable prey. That is, for intraguild predation to be advantageous the benefits should outweigh the costs.

ACKNOWLEDGEMENTS. This work was supported by a grant awarded by the Fonds National de la Recherche scientifique, Le Commissariat général aux Relations extérieures de la Communauté française de Belgique and The British Council to J.-L. Hemptinne and A.F.G. Dixon.; C. Gauthier benefited from a Pic Erasmus grant of the E U.

\section{REFERENCES}

Agariwala B.K. \& Dixon A.F.G. 1992: Laboratory study of cannibalism and interspecific predation in ladybirds. Ecol. Entomol. 17: 303-309.

Agarwala B.K., Bhattacharya S. \& Bardhanroy P. 1998: Who eats whose eggs ? Intra- versus inter-specific interactions in starving ladybird beetles predaceous on aphids. Ethol. Ecol. Evol. 10: 361-368.

BANKS C.J. 1955: An ecological study of Coccinellidae (Col.) associated with Aphis fabae Scop. on Vicia faba. Bull. Entomol. Res. 46: 561-587.

BANKS C.J. 1956: Observations on the behaviour and mortality in Coccinellidae before dispersal from the egg shells. Proc. $R$ Entomol. Soc. Lond. 31: 56-60.

Barczak T., KaCzorowski G. \& Burmistrzak M. 1996 Coccinellid beetles (Coccinellidae, Col.) associated with populations of Aphis fabae Scop. - complex (Aphididae, Hom.) on spindle bush. Preliminary results. In Narkiewicz-Jodko J., Cichocka E., Nawrocka B. \& Goszcynski W. (eds): Aphids and Other Homopterous Insects, vol. 5. Polish Academy of Sciences Vth Division, Skierniewice, pp.15-22.

Blackman R.L. 1965: Studies on specificity in Coccinellidae. Ann. Appl. Biol. 56: 336-338.

Blackman R.L. 1967: The effects of different aphid foods on Adalia bipunctata L. and Coccinella 7-punctata L. Ann. Appl. Biol. 59: 207-219.
CANard M. \& Duelli P. 1984: Predatory behavior of larvae and cannibalism. In Canard M., Semeria Y. \& New T.R. (eds): Biology of Chrysopidae. Dr. W. Junk, Boston, MA, pp. 92-100.

Cottrell T.E. \& Yeargan K.V. 1998: Intraguild predation between an introduced Lady Beetle, Harmonia axyridis (Coleoptera: Coccinellidae) and a native Lady Beetle, Coleomegilla maculata (Coleoptera: Coccinellidae). J. Kans. Entomol. Soc. 71: 159-163.

de Jong P.W., Holloway G.J., Brakefield, P.M. \& de Vos H. 1991: Chemical defence in ladybird beetle (Coccinellidae). II. The amount of reflex fluid, the alkaloid adaline and individual variation in defence in 2-spot ladybirds (Adalia bipunctata). Chemoecology 2: 15-19.

Dixon A.F.G. 1998: Aphid Ecology. Chapman \& Hall, London, $300 \mathrm{pp}$.

Dixon A.F.G. \& Russel R.J. 1972: The effectiveness of Anthocoris nemorum and A. confusus (Heteroptera: Anthocoridae) as predators of the sycamore aphid, Drepanosiphum platanoides. II. Searching behaviour and the incidence of predation in the field. Entomol. Exp. Appl. 15: $35-50$.

Eisner T., Attygale A.B., Conner W.E., Eisner M., Mac Leod E. \& Meinwald J. 1996: Chemical defense in a green lacewing (Ceraeochrysa smithii). Proc. Natl. Acad. Sci. USA 93: $3280-3283$.

Frazer J.F.D. \& Rothschild M. 1960: Defence mechanisms in warningly coloured moths and other insects. Proc. 11th Internat. Congr.Entomol., Wien, Verhandlungen B 3: 249-256.

HEMPTINNE J-L. 1989: Ecophysiologie d'Adalia bipunctata (Coleoptera, Coccinellidae). $\mathrm{PhD}$ Thesis, Université Libre de Bruxelles, Belgium, $156 \mathrm{pp}$.

Hemptinne J-L., Lognay G. \& Dixon A.F.G. 1998: Mate recognition in the two-spot ladybird beetle, Adalia bipunctata: role of chemical and behavioural cues. J. Insect Physiol. 44: $1163-1171$.

Hemptinne, J-L. \& Naisse J. 1988: Life cycle strategy of Adalia bipunctata (L.) (Col., Coccinellidae) in a temperate country. In Niemczyk E. \& Dixon A.F.G. (eds): Ecology and Effectiveness of Aphidophaga, SPB Academic Publ., The Hague, pp. 71-77.

Holloway G.J., de Jong P.W., Brakefield P.M. \& de Vos H. 1991: Chemical defence in ladybird beetles (Coccinellidae). I. Distribution of coccinelline and individual variation in defence in 7-spot ladybirds (Coccinella septempunctata). Chemoecology 21:7-14.

HoNÉK A. 1985: Habitat preference of aphidophagous coccinellids (Coleoptera). Entomophaga 30: 253-264.

Lucas E., Coderre D. \& Brodeur J. 1998: Intraguild predation among aphid predators: characterization and influence of extraguild prey density. Ecology 79: 1084-1092.

Marples N.M., BRAKeField P. \& CowIE R.J. 1989: Differences between the 7-spot and the 2-spot ladybird beetles (Coccinellidae) in their toxic effects on a bird predator. Ecol. Entomol. 14: 79-84.

NEDVËD O. 1999: Host complexes of predaceous ladybeetles (Col., Coccinellidae). J. Appl. Entomol. 123: 73-76.

OBRYCKI J.J., Giles K.L. \& ORMORd A.M. 1998a: Experimental assessment of interactions between larval Coleomegilla maculata and Coccinella septempunctata (Coleoptera: Coccinellidae) in field cages. Envir. Entomol. 27: 1280-1288.

OBRYCKI J.J., GILes K.L. \& ORMORD A.M. 1998b: Interactions between an introduced and indigenous coccinellid species at different prey densities. Oecologia 117: 279-285.

Pasteels J.-M., Deroe C., Turrch B. Braekman J.C., Daloze D. \& Hootele C. 1973: Distribution et activités des alcalod'des 
défensifs des Coccinellidae. J. Insect Physiol. 19: 1771-1784.

Polis G.A., Myers C.A. \& Holt R.D. 1989: The ecology and evolution of intraguild predation: potential competitors that eat each other. Annu. Rev. Ecol. Syst. 20: 297-330.

RADWAN Z. \& LövEI G.L. 1982: Distribution and bionomics of ladybird beetles (Col., Coccinellidae) living on an apple orchard near Budapest, Hungary. Z. Angew. Entomol. 94: 169-175.

Radwan Z. \& LöVei G.L. 1983a: Aphids as prey for the coccinellid Exochomus quadripustulatus. Entomol. Exp. Appl. 34: $283-286$.

RADWAN Z. \& LÖVEI G.L. 1983b: Structure and seasonal dynamics of larval, pupal, and adult coccinellid (Col., Coccinellidae) assemblages in Hungary. Z. Angew. Entomol. 96: 396-408.

Remaudière G. \& Leclant F. 1971: Le complexe des ennemis naturels des aphides du pęcher dans la moyenne vallée du Rhone. Entomophaga 16: 255-267.

Rosenhem J.A., Wilhort L.R. \& ARMer C.A. 1993: Influence of intraguild predation among generalist insect predators on the suppression of an herbivore population. Oecologia 96: 439-449.

Rosenheim J.A., Kaya H.K., Ehler L.E., Marois J.J. \& JafFeE
B.A. 1995: Intraguild predation among biological control agents: theory and evidence. Biol. Control 5: 303-335.

SCHEllhorN N.A. \& ANDOW D.A. 1999: Cannibalism and interspecific predation: role of oviposition behavior. Ecol. Appl. 9: 418-428.

SChELlhorn N.A. \& ANDow D.A. 2000: Mortality of coccinellid beetle larvae and pupae when prey becomes scarce. Envir. Entomol. 26: 1092-1100.

SmeE C. 1922: British ladybird beetles. Their control of aphids. The Fruit Grower 53: 675-676.

Sмттн B.D. 1966: Effects of parasites and predators on a natural population of the aphid Acyrthosiphon spartii (Koch) on broom (Sarothamnus scoparius L.). J. Anim. Ecol. 35: 255-267.

Taylor A.J., Mưller C.B. \& Godfray H.C.J. 1998: Effect of aphid predators on oviposition behaviour in aphid parasitoids. J. Insect Behav. 11: 297-302.

Trouré C., Lédée S., Brun J. \& Ferran A. 1996: Lutte biologique contre les pucerons du houblon. Phytoma 486: 41-44.

ZAR J.H. 1996: Biostatistical Analysis. Prentice-Hall International Inc., Upper Saddle River, N.J., 662 pp.

Received December 8, 1999; accepted July 28, 2000 